\title{
The role of BER and NER gene polymorphisms and their expression in glaucoma pathogenesis
}

\section{Rola polimorfizmów oraz ekspresji genów BER i NER w patogenezie jaskry}

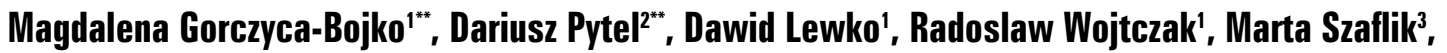 \\ Jerzy Szaflik', Jacek P. Szaflik², Ireneusz Majsterek** \\ Department of Clinical Chemistry and Biochemistry, Medical University in Lodz, Lodz, Poland \\ Head: professor Ireneusz Majsterek, MD, PhD \\ 2 Department of Biochemistry and Molecular Biology, Hollings Cancer Center, Medical University of South Carolina, \\ Charleston, United States \\ Head: J. Alan Diehl, PhD \\ 3 Department of Ophthalmology, SPKSO Ophthalmic Hospital, Medical University of Warsaw, Warsaw, Poland \\ Head: professor Jacek P. Szaflik, MD, PhD \\ 4 Laser Eye Microsurgery Center, Warsaw, Poland \\ Head: professor Jerzy Szaflik, MD, PhD \\ Corresponding author: \\ prof. Ireneusz Majsterek, \\ ** These authors contributed equally to the work: \\ dr Magdalena Gorczyca-Bojko and dr Dariusz Pytel
}

Ahstract: Introduction: Glaucoma is the second most common cause of blindness globally. Glaucoma development has been attributed to impaired base excision repair (BER) and, possibly, altered nucleotide excision repair (NER).

Aim: The aim of this study was to examine the influence of the NER and BER DNA repair pathways on glaucoma development. The genotypes of XPD, XPC, XRCC1 and ADPRT SNPs and their mRNA expression level were determined.

Material and Methods: The study included 200 patients diagnosed with POAG and 200 healthy age-matched controls. PCR-RFLP was employed for genotyping the study and control groups. Real-time PCR was used to evaluate the level of mRNA expression in the studied genes.

Results: A relationship was found between XRCC1 and XPD gene polymorphisms and glaucoma pathogenesis. However, no significant changes were found between patients and controls with regard to the level of mRNA expression. Conclusion: Both BER and NER may play a part in glaucoma pathogenesis.

Key words: $\quad$ glaucoma, gene polymorphisms, BER, NER

Ahstrakt: $\quad$ Wstęp: Jaskra jest drugą przyczyną utraty wzroku w krajach wysokorozwiniętych. Ostatnie badania wykazały związek mechanizmu naprawy DNA przez wycinanie zasad azotowych (BER) z podwyższonym ryzykiem rozwoju jaskry pierwotnej otwartego kąta. Naprawa DNA przez wycinanie nukleotydów (NER) może również stanowić czynnik ryzyka dla nieprawidłowo funkcjonującego mechanizmu naprawy DNA.

Cel: Celem niniejszych badań była ocena związku mechanizmu naprawy DNA przez wycinanie zasad azotowych oraz wycinanie nukleotydów z rozwojem jaskry pierwotnej otwartego kąta. Analizie poddano poziomy ekspresji mRNA oraz polimorfizmy następujących genów XPD, XPC, XRCC1 i ADPRT.

Materiat i metody: Badania przeprowadzono na grupie 200 pacjentów z jaskrą pierwotną otwartego kąta oraz na 200 osobach z grupy kontrolnej, które wybrano spośród osób, które nie wykazywały objawów jaskry pierwotnej otwartego kąta. Genotypy dla polimorfizmów genu XPD, XPC, XRCC1 i $A D P R T$ analizowano metodą polimorfizmu długości fragmentów restrykcyjnych PCR (PCR-RFLP), natomiast poziom mRNA został oznaczony techniką Real-Time PCR.

Rezultaty: Badania wykazały związek polimorfizmów genów XRCC1 oraz XPD z patogenezą jaskry pierwotnej otwartego kąta. Nie wykazano natomiast zmian w poziomie mRNA badanych genów.

Wnioski. Rezultaty wynikające z przedstawionych badań mogą sugerować, że polimorfizmy genów XRCC1 oraz XPD zaangażowanych w mechanizmy naprawy DNA mogą mieć związek z ryzykiem rozwoju jaskry pierwotnej otwartego kąta.

Stowa kluczowe: jaskra, polimorfizm genów, BER, NER

The authors declare no conflict of interest/ Autorzy zgłaszają brak konfliktu interesów w związku z publikowaną pracą

\section{Introduction}

In 2010, 60.5 million new glaucoma cases were diagnosed, and epidemiological studies indicate that the prevalence is still increasing. It is suggested that in 2020, the number of people with glaucoma may reach 79.6 million. Global reports indicate that primary open angle glaucoma (POAG) is the most common 
form, responsible for the bilateral vision loss in 4.5 million people in 2010. In 2020, this number may rise to 5.9 million (1).

Glaucoma is defined as optic nerve damage caused by high intraocular pressure (IOP). It is classified as a neurodegenerative eye disorder leading to irreversible vision loss. Although the molecular basis of POAG remains not fully understood, despite numerous studies, oxidative stress, elevated IOP (more than $21 \mathrm{mmHg}$ ), age (over 40 ), sex, race, diabetes mellitus type 2 and genetic predisposition are believed to be the most important POAG risk factors. In the 1980s, Alvaradro et al. postulated a relationship between the loss of trabecular meshwork (TM) cells and long-term impact of oxidative stress in patients with glaucoma (2). This has since been confirmed in some studies: For instance, Izotti et al. report that elevated levels of oxidative DNA damage correlate with increased IOP (3). Furthermore, the in vitro and in vivo studies have indicated that hydrogen peroxide treatment leads to a decrease in the adhesion of human TM cells and alters their cellular integrity. It has also been indicated that irrigation of TM cells with hydrogen peroxide may lead to changes in the drainage of the aqueous humor from the anterior chamber of the eye in calves (4).

Reactive oxygen species (ROS) generated under the oxidative stress conditions may induce DNA damage, with the most common form of damage being oxidative DNA lesions. Left unrepaired, these can lead to genetic instability, mutations and increasing levels of chromosomal aberrations. Therefore, several DNA repair mechanisms have developed that guard genome integrity and reduce the risk of such mutations, and these are needed to prevent carcinogenesis and neurodegeneration by removing remove DNA lesions (5). The main mechanism responsible for removing oxidative DNA damage is known as base excision repair (BER), a coordinated mechanism comprising sequential reactions responsible for damage detection, processing, gap filling and ligation.

The present study examines the genes encoding main BER proteins, in particular, new polymorphic variants of the XRCC1 and $A D P R T$ genes. XRCC1 (X-ray repair cross-complementing) is a scaffold protein in the BER mechanism. It recruits poly(ADPribose) polymerase, DNA polymerase- $\beta$ and DNA ligase Ill $\alpha$ to the damage site to form a complete repair complex (6). An elevated prevalence of spontaneous chromosome aberrations and deletions were found in XRCC1 knockout mice and XRCC1 mutant cells (7), and numerous polymorphic variants of the XRCC1 gene have since been identified, including several non-synonymous single-nucleotide polymorphisms (SNPs) in the coding region. The present study examines the $-77 \mathrm{~T} / \mathrm{C}$ polymorphism of the $X R C C 1$ gene. This new polymorphic variant of $X R C C 1$ found within the $5^{\prime}$ untranslated region (8) may be associated with reduced XRCC1 expression (9). It also examines the 1672GA polymorphism of the ADPRT gene, known to encode poly(ADP-ribose) polymerase 1 (PARP-1, also known as ADPRT), a nuclear multifunctional enzyme activated in response to various forms of DNA damage. This protein participates in a wide range of activities including DNA repair, proliferation, stress response, cell death, genomic stability and malignancy (10).

A growing number of studies postulate that another mechanism known as nucleotide excision repair (NER) may also participate in neutralizing oxidative DNA lesions (11) by protecting cells against oxidative base modifications, alongside cyclobutane pyrimidine dimers (CPDs) and pyrimidine (6-4) pyrimidone products (64PP). NER has been proposed as a backup repair mechanism if a nuclear BER glycosylase is defective. It is important to note, though, that the NER system is not present in mitochondria.

The present study examines two main NER proteins: XPC and XPD. XPC, the crucial NER enzyme, plays a role in recognizing damage, and any changes in its activity may be associated with changes in oxidative DNA repair and disturbances in redox homeostasis (12). Furthermore, the XRCC1 and ADPRT1 complex is believed to be an important co-factor for the BER pathway (13). The 939 Lys/Gln XPC gene polymorphism was chosen for analysis in the present study, as it is believed to be associated with decreased XPC enzyme activity and may be connected with the pathogenesis of various diseases (14). The XPD protein is part of transcriptional factor of IIH, and plays an important role in managing cell cycle, apoptosis and transcription. Mutations of the XPD gene may downregulate certain proteins, leading to changes in the NER pathway (15). The best studied polymorphism of the XPD gene is $751 \mathrm{Lys} / \mathrm{Gln}$, which is thought to induce changes in XPD function and decrease the activity of TGIIH complex (16). These changes may be crucial for the pathogenesis of numerous diseases, including glaucoma (17) and cataract (18). Hence, the main aim of the present study was to assess the role of BER as well as NER mechanism in the pathogenesis of POAG.

\section{Aim}

Despite numerous studies, the DNA repair mechanism and its influence on the pathogenesis of glaucoma remain poorly understood; therefore, the aim of this study was to determine the role of NER and BER in glaucoma development. It involved determination of the XPD, XPC, XRCC1 and ADPRT gene polymorphism genotypes, as well as their mRNA expression level in glaucoma patients. Furthermore, the level of expression of XPC and XPD, the two main NER proteins that are crucial for recognizing DNA damage, and the levels of their genetic polymorphisms (939 Lys/Gln for XPC and 751 Lys/Gln for XPD) were measured. Finally, as the XRCC1 and ADPRT1 complex is known to be an important co-factor for BER, the study examined the -77 T/C XRCC1 gene polymorphism, with regard to its influence on the risk of POAG development, and the G1672A polymorphism of $A D P R T$, located in the promoter region.

\section{Materials and Methods}

\subsection{Material}

The study included 200 patients diagnosed with POAG (65 women and 135 men, mean age $72 \pm 10$ ) hospitalized in the Department of Ophthalmology, Medical University of Warsaw, and 200 healthy controls ( 53 women and 147 men) age-matched controls (mean age $71 \pm 12$ years), selected from subjects without glaucoma symptoms. All patients and controls were Caucasian. The patient characteristics are presented in Table 1. The correct IOP value is indicated from the applied therapy. At the time of the study, the POAG patients were being treated topically with one or a more typical anti-glaucoma medications, including beta 


\begin{tabular}{|c|c|c|c|}
\hline & Parameters & $\begin{array}{c}\text { Patients } \\
n=200\end{array}$ & $\begin{array}{c}\text { Controls } \\
n=\end{array}$ \\
\hline \multirow{4}{*}{ Number } & Sex (male/female) & $65 / 135$ & $53 / 147$ \\
\hline & Hypertension* & 121 & 157 \\
\hline & Low blood pressure ${ }^{* *}$ & 56 & 81 \\
\hline & Vascular disease & 79 & 114 \\
\hline \multirow{6}{*}{ Mean \pm SD } & Age (years) & $72 \pm 10$ & $71 \pm 12$ \\
\hline & Intraocular pressure, IOP $(\mathrm{mmHg})$ & $12.82 \pm 2.9$ & \\
\hline & Cup-to-disc ratio (c/d) (right eye/left eye) & $0.74 / 0.74$ & PNM \\
\hline & Rim area (RA) (right eye/left eye) & $1.61 / 1.30$ & PNM \\
\hline & Retinal Nerve Fiber Layer (RNFL) (right eye/left eye) & $2.23 / 1.44$ & PNM \\
\hline & Nerve Fiber Index (NRI) (right eye/left eye) & $31.4 / 27.4$ & PNM \\
\hline
\end{tabular}

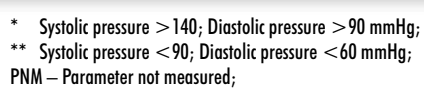

Tab. I. The clinical parameters characteristic of open-angle glaucoma (POAG) patients and controls.

Tab. I. Parametry kliniczne charakterystyczne dla pacjentów z jaskrą pierwotną otwartego kąta przesączania (JPOK) oraz dla grupy kontrolnej.

blockers (e.g., Timolol), prostaglandin analogs (e.g., Latanoprost), carbonic anhydrase inhibitors (e.g., Dorzolamide) and alpha2 agonists (e.g., Brimonidine). All patients with POAG were assessed using the Heidelberg Retinal Tomography (HRT).

The study focused on the following clinical parameters: disc ratio $(\mathrm{c} / \mathrm{d})$, rim area (RA), Retinal Nerve Fiber Layer (RNFL), visual field (VF) and nerve fiber layer (NFL). The range of POAG progression stages is presented in the attached tables. The volume ranges for each clinical parameter complied with the guidelines of the European Glaucoma Society (Terminology and Guidelines for Glaucoma 2nd Edition, Dogma, Savona 2003, Italy). Additionally, patient age, family history and details of any current or past cancer or genetic disease were ascertained from their medical records.

Patients were excluded from the study if they were subject to any of the following conditions which could possibly interfere with the results of the study: the use of eyedrops or other anti-glaucoma medications, history of ocular surgery or laser treatment in the eye from which the specimens were to be collected, current or past treatment with glucocorticosteroids or immunosuppressive therapy (unless discontinued at least one year prior to surgery and specimen collection), use of non-steroidal anti-inflammatory drugs (with the exception of low-dose aspirin, which had to be stopped seven days prior to surgery and specimen collection), or prior and concurrent systemic antibiotic treatment within 7 days prior to enrolment.

The study protocol was reviewed and approved by the Local Ethics Committee of the Medical University of Warsaw and Medical University of Lodz. Written consent was obtained from each participant prior to enrolment.

\subsection{Methods}

\subsubsection{Genotype determination}

Genomic DNA was isolated from peripheral blood leukocytes using the OIAamp DNA Blood Mini Kit for isolation of high molecular-weight DNA (Qiagen, Chatsworth, CA, USA) according to the manufacturer's instructions. The genotypes of $X P D$, $X P C, X R C C 1$ and $A D P R T$ gene polymorphisms were determined by the PCR-based restriction fragment length polymorphism (PCR-RFLP) method. The sequences, cycling conditions, reaction enzyme and product size are presented in Table 2.

\begin{tabular}{|c|c|c|c|c|}
\hline Gene polymorphism & Primer sequence & $\begin{array}{l}\text { Annealing } \\
{\left[{ }^{\circ} \mathrm{C}\right]}\end{array}$ & $\begin{array}{c}\text { PCR } \\
\text { product }[\mathrm{bp}]\end{array}$ & Enzyme \\
\hline XPD & $\begin{array}{l}\text { 5'-GCC CGC TCT GGA TTA TAC G-3 } \\
\text { 5'-CTA TCA TCT CCT GGC CCC C-3' }\end{array}$ & 62 & & Pstl \\
\hline XPC & $\begin{array}{l}\text { 5'-GTA GTG GGG GCA GCA GCA AC-3' } \\
\text { 5'-GAT GCA GGAGGT GGACTC T-3 }\end{array}$ & 63 & & Pvull \\
\hline G1672A ADPRT/PARP1 & $\begin{array}{c}\text { F- 5' GCG AGA CCC TGT CCC TAA 3', } \\
\text { R- 5'-TCC CCC CTT TTA TTT TTG GAG ACTG-3 }\end{array}$ & 62 & 187 & Bsh1236 \\
\hline -77TC XRCC1 & $\begin{array}{l}\text { 5'-GAG GAA ACG CTCGTT GCT AAG - } 3^{\prime \prime} \\
5^{\prime} \text {-TCC TCA TTA ATT CCC TCA CGT C-3'. }\end{array}$ & 62 & 336 & BsrBl1 \\
\hline
\end{tabular}

Tab. II. Primer sequences and restriction endonucleases used in the gene polymorphisms analysis by polymerase chain reaction-restriction fragment length polymorphism (PCR-RFLP).

Tab. II. Sekwencje starterów oraz enzymy restrykcyjne stosowane w analizie polimorfizmów genów metodą polimorfizmu długości fragmentów restrykcyjnych (PCR-RFLP). 


\subsubsection{Real Time Quantitative PCR}

\subsubsection{RNA isolation and cDNA synthesis}

Blood samples were collected in $5 \mathrm{ml}$ EDTA tubes. Total RNA was isolated from peripheral lymphocytes using Fenozol reagent (A\&A Biotechnology, Gdynia, Poland) according to the manufacturer's protocol. Total RNA was extracted from 20 subjects with POAG and 20 healthy controls. RNA was eluted in 50 $\mu \mathrm{l}$ RNase-free water, and stored at $-20^{\circ} \mathrm{C}$. The yields were quantified spectrophotometrically. RNA with a $260 / 280 \mathrm{~nm}$ ratio in the range of 1.8-2.0 was considered high quality and was used for further analysis. First-strand cDNAs were synthesized by reverse transcription of $1 \mu \mathrm{g}$ of total RNA using AffinityScript OPCR cDNA Synthesis Kit (Agilent Technologies, Santa Clara, CA, USA) following the manufacturer's protocol.

\subsubsection{Real Time Quantitative PCR - procedure}

For real-time PCR analysis of XRCC1 and ADPRT mRNA, Brilliant II SYBR ${ }^{\circledR}$ QPCR and QRT-PCR Master Mix Kits (Agilent Technologies, Santa Clara, CA, USA) were used according to the manufacturer's instruction. The GAPDH gene was used as the internal sample control. The sequence of specific primers for GAPDH and target genes are presented in Table 3 . The RT-qPCR reaction was carried out using the Mx3005P from Agilent Technologies. The sequences, cycling conditions and product size are presented in Table 3. The reactions were performed in duplicate.
Fisher's exact test was used. The non-parametric Mann-Whitney U-test was applied to determine the levels of mRNA expression in the blood of the POAG patients and healthy subjects. Non-parametrical statistical tests (ANOVA with post hoc Tukey's HSD test) were applied to compare the level of mRNA expression with genotypes of each polymorphism in studied specimens. A p-value below 0.05 was considered statistically significant. Statistical analysis was performed using STATISTICA 6.0 software (Statsoft, Tulsa, OK, USA).

\section{Results:}

The distribution of genotypes and alleles of XRCC1, XPD and $X P C$ genes corresponded to the predicted HW proportion $(P<0.05)$ in both control and POAG groups. However, the distribution of the genotypes and alleles of the ADPRT gene did not $(\mathrm{P}>0.05)$.

Initially, the relationship between studied polymorphic variants and risk of POAG development was examined. Significant differences were found in the distribution of the XRCC1 and XPD genes with regard to POAG pathogenesis. Although we initially postulated that the presence of the Lys/Gln XPD SNP was associated with a higher risk of POAG (OR 1.59; 95\% Cl 1.02- 2.48; $\mathrm{P}=0.03$ ), it was found that the presence of the $-77 \mathrm{~T} / \mathrm{C}$ genotype of XRCC1 decreased POAG risk (OR 0.62; 95\% Cl 0.41- 0.97; $\mathrm{P}=0.03$ ). The results are presented in Table 4.

To determine whether the presence of the studied SNPs may play a role in POAG progression, the present study focused

\begin{tabular}{|c|c|c|}
\hline Gene polymorphism & Primer sequence & $\begin{array}{c}\text { PCR } \\
\text { product [bp] }\end{array}$ \\
\hline ADPRT/PARP1 & F: 5'TCTTTGATGTGGAAAGTATGAAGAA 3' \\
R: 5'GGCATCTTCTGAAGGTCGAT 3' & 64 \\
\hline XRCC1 & $\begin{array}{l}\text { F 5'AGCCTCCTGATCTGCCAGT 3' } \\
\text { F 5'AGCCTCCTGATCTGCCAGT 3' }\end{array}$ & 77 \\
\hline GAPDH & F: 5'-CACCTTCCCCATGGTGTCT-3' \\
R: 5'-CCCCGGTTCTATAATTGAGC-3' & 120 \\
\hline
\end{tabular}

Tab. III. Primer sequences used in QRT-PCR analysis.

Tab. III. Sekwencje starterów stosowane w analizie metodą ilościowej reakcji łańcuchowej polimerazy DNA (QRT-PCR).

A positive result was defined by a threshold cycle $(\mathrm{Ct})$ value lower than 40 (the $\mathrm{Ct}$ value is determined by the number of cycles needed to exceed the background signal). The abundance of target gene mRNA in the studied material was quantified by the $\Delta$ Ct method.

\section{Statistical analysis}

To compare the distributions of demographic variables and selected risk factors between patients and controls, the Chi-square test was used. The observed numbers of cases for each genotype in the study and control group were compared with the expected number according to the Hardy-Weinberg principle, using the $\chi 2$ test. The association between case-control status and each polymorphism, measured by the odds ratio (OR) and its corresponding 95\% confidence interval (Cl), was estimated using an unconditional multiple logistic regression model. When calculating the probability, Pearson's correction was used, and if the expected cell values were less than 5 , on clinical parameters crucial for POAG development. It was found that the $C D$ ratio was associated with the relationship between early and advanced glaucoma. We suggested that the 1672G/A genotype of $A D P R T$ gene increased risk of POAG progression (OR 3.03; 95\% Cl 1.12- 8.16; $\mathrm{P}=0.03$ ). Surprisingly, the $-77 \mathrm{C} / \mathrm{C}$ genotype (OR $0.47 ; 95 \% \mathrm{Cl} 0.24-0.93 ; \mathrm{P}=0.02$ ) and $-77 \mathrm{C}$ (OR 0.70; 95\% $\mathrm{Cl} 0.51-0.97 ; \mathrm{P}=0.02$ ) allele decreased the risk of POAG progression. The analysis is summarized in Table 5 .

Consecutive analyses were based on RA. The presence of the $1672 \mathrm{G} / \mathrm{A}$ (OR $6.67 ; 95 \% \mathrm{Cl} 1.39-31.85 ; \mathrm{P}=0.02$ ) genotype and the $1692 \mathrm{~A}$ allele of the $A D P R T$ gene (OR $3.03 ; 95 \% \mathrm{Cl} 1.12$ 8.16; $P=0.03$ ) were found to be associated with POAG progression (early glaucoma changes vs norm). In addition, the $\mathrm{Gln} / \mathrm{G} \mathrm{ln}$ genotype of the XPC gene correlated with an increased risk of POAG progression (OR 2.33; $95 \% \mathrm{Cl} 1.01-5.37 ; \mathrm{P}=0.04$ ). Progression analysis is summarized in Table 6 .

The next stage of the research included the assessment of XRCC1 and ADPRT expression. The expression analysis of 


\begin{tabular}{|c|c|c|c|c|}
\hline Genotype or allele & POAG patients & Control subjects & OR (95\%Cl) & $\mathbf{p}$ \\
\hline -77TC XRCC1 & $n=193$ & $n=200$ & & \\
\hline $\mathrm{TT}$ & $77(0.40)$ & $62(0.31)$ & Ref & \\
\hline TC & $86(0.45)$ & $110(0.55)$ & $0.62(0.41-0.97) \downarrow$ & 0.03 \\
\hline CC & $30(0.15)$ & $28(0.14)$ & $0.86(0.47-1.59)$ & 0.64 \\
\hline$T$ & $240(0.64)$ & $234(0.58)$ & Ref & \\
\hline C & $146(0.46)$ & $166(0.41)$ & $0.86(0.64-1.14)$ & 0.29 \\
\hline ADPRT & $n=189$ & $n=194$ & & \\
\hline $\mathrm{GG}$ & $139(0.43)$ & $138(0.71)$ & Ref & \\
\hline $\mathrm{GA}$ & $29(0.15)$ & $45(0.23)$ & $0.64(0.37-1.07)$ & 0.09 \\
\hline $\mathrm{AA}$ & $21(0.11)$ & $11(0.06)$ & $1.60(0.77-3.33)$ & 0.20 \\
\hline G & $307(0.81)$ & $321(0.81)$ & Ref & \\
\hline A & $71(0.19)$ & $75(0.19)$ & $0.98(0.69-1.42)$ & 0.51 \\
\hline XPC & $n=200$ & $n=201$ & & \\
\hline Lys/Lys & $32(0.16)$ & $33(0.16)$ & Ref & \\
\hline Lys/Gln & $85(0.42)$ & $97(0.48)$ & $0.90(0.51-1.59)$ & 0.73 \\
\hline $\mathrm{G} \ln / \mathrm{G} \ln$ & $83(0.42)$ & $71(0.35)$ & $1.20(0.67-2.15)$ & 0.53 \\
\hline Lys & $149(0.37)$ & $163(0.41)$ & Ref & \\
\hline Gln & $251(0.63)$ & $239(0.59)$ & $1.14(0.86-1.52)$ & 0.55 \\
\hline$X P D$ & $n=195$ & $n=200$ & & \\
\hline Lys/Lys & $73(0.37)$ & $90(0.45)$ & Ref & \\
\hline Lys/Gln & $88(0.45)$ & $68(0.34)$ & $1.59(1.02-2.48) \uparrow$ & 0.03 \\
\hline $\mathrm{Gln} / \mathrm{Gln}$ & $34(0.17)$ & $42(0.21)$ & $0.99(0.58-1.72)$ & 0.55 \\
\hline Lys & $234(0.60)$ & $258(0.61)$ & Ref & \\
\hline Gln & $156(0.40)$ & $162(0.39)$ & $1.06(0.80-1.41)$ & 0.72 \\
\hline
\end{tabular}

Tab. IV. The genotype and allele frequency and odds ratios (OR) of the gene polymorphisms in open-angle glaucoma (POAG) patients and controls.

Tab. IV. Rozkład genotypów i częstotliwość alleli oraz iloraz szans (OR) dla polimorfizmów genów w grupie pacjentów z jaskrą pierwotną otwartego kąta przesączania (JPOK) oraz grupie kontrolnej.

\begin{tabular}{|c|c|c|c|c|}
\hline Genotype or allele & Advance & Early & OR (95\% Cl) & p \\
\hline -77TC XRCC1 & $n=176$ & $n=134$ & & \\
\hline TT & $74(0.42)$ & $45(0.34)$ & Ref & \\
\hline TC & $81(0.46)$ & $62(0.46)$ & $0.79(0.48-1.30)$ & 0.36 \\
\hline CC & $21(0.12)$ & $27(0.20)$ & $0.47(0.24-0.93)$ & 0.02 \\
\hline $\mathrm{T}$ & $229(0.65)$ & $152(0.57)$ & Ref & \\
\hline C & $123(0.35)$ & $116(0.43)$ & $0.70(0.51-0.97)$ & 0.02 \\
\hline Genotype or allele & advance & Early & OR (95\%CI) & $\mathbf{p}$ \\
\hline adprt & $n=128$ & $n=71$ & & \\
\hline GG & $96(0.75)$ & $53(0.75)$ & Ref & \\
\hline $\mathrm{GA}$ & $15(0.12)$ & $13(0.18)$ & $3.03(1.12-8.16)$ & 0.03 \\
\hline AA & $17(0.13)$ & $5(0.07)$ & $1.88(0.66-5.37)$ & 0.17 \\
\hline G & $207(0.80)$ & $119(0.84)$ & Ref & \\
\hline$A$ & $49(0.20)$ & $23(0.16)$ & $1.22(0.71-2.11)$ & 0.46 \\
\hline
\end{tabular}

Tab. V. The genotype and allele frequency and odds ratios $(O R)$ of the gene polymorphisms in open-angle glaucoma (POAG) patients based on the cup-to-disc ratio (CDR).

Tab. V. Rozkład genotypów i częstotliwość alleli oraz iloraz szans (OR) dla polimorfizmów genów w grupie pacjentów z jaskrą pierwotną otwartego kąta przesączania (JPOK) oraz grupie kontrolnej w odniesieniu do parametru stosunku średnicy zagłębienia do średnicy tarczy nerwu wzrokowego (CDR). 


\begin{tabular}{|c|c|c|c|c|c|c|c|c|c|c|}
\hline $\begin{array}{l}\text { Genotype } \\
\text { or allele }\end{array}$ & Advance & Middle & Early & Norm & $\begin{array}{c}\text { OR } \\
(95 \% \mathrm{Cl})\end{array}$ & $\mathbf{p}$ & $\begin{array}{c}\text { OR } \\
(95 \% \mathrm{Cl})\end{array}$ & p & $\begin{array}{c}\text { OR } \\
(95 \% \mathrm{Cl})\end{array}$ & $\mathbf{p}$ \\
\hline ADPRT & $n=54$ & $n=80$ & $n=11$ & $n=63$ & & & & & & \\
\hline GG & $37(0.66)$ & $59(0.74)$ & $5(0.45)$ & $50(0.79)$ & Ref & & Ref & & Ref & \\
\hline $\mathrm{GA}$ & $9(0.17)$ & $14(0.17)$ & $4(0.36)$ & $6(0.09)$ & $2.03(0.66-6.19)$ & 0.21 & $1.98(0.71-5.53)$ & 0.19 & $6.67(1.39-31.85)$ & 0.02 \\
\hline AA & $8(0.15)$ & $7(0.09)$ & $2(0.18)$ & $7(0.11)$ & $1.54(0.51-4.64)$ & 0.43 & $0.85(0.28-2.58)$ & 0.76 & $2.86(0.46-17.64)$ & 0.25 \\
\hline G & $83(0.77)$ & $132(0.82)$ & $14(0.64)$ & $106(0.84)$ & Ref & & Ref & & Ref & \\
\hline$A$ & $25(0.23)$ & 28 & $8(0.36)$ & $20(0.16)$ & $1.60(0.83-3.07)$ & 0.16 & $1.12(0.60-2.11)$ & 0.72 & $3.03(1.12-8.16)$ & 0.03 \\
\hline XPD & $n=70$ & $n=107$ & $n=16$ & $n=83$ & & & & & & \\
\hline Lys/Lys & $31(0.44)$ & $43(0.40)$ & $6(0.38)$ & $23(0.28)$ & Ref & & Ref & & Ref & \\
\hline Lys/Glu & $25(0.36)$ & $41(0.38)$ & $9(0.56)$ & $45(0.54)$ & $0.41(0.19-0.85)$ & 0.01 & $0.49(0.25-0.94)$ & 0.03 & $0.77(0.24-2.42)$ & 0.64 \\
\hline Gln/Glu & $14(0.20)$ & $23(0.22)$ & $1(0.06)$ & $15(0.18)$ & $0.69(0.28-1.71)$ & 0.42 & $0.82(0.36-1.87)$ & 0.64 & $0.26(0.03-2.34)$ & 0.20 \\
\hline Lys & $87(0.62)$ & $127(0.40)$ & $21(0.68)$ & $91(0.55)$ & ref & & Ref & & Ref & \\
\hline Gln & $53(0.37)$ & $187(0.60)$ & $11(0.32)$ & $75(0.45)$ & $0.74(0.47-1.17)$ & 0.19 & $0.74(0.47-1.17)$ & 0.19 & $0.64(0.28-1.40)$ & 0.26 \\
\hline XPC & $n=69$ & $n=93$ & $n=31$ & $n=79$ & & & & & & \\
\hline Lys/Lys & $12(0.17)$ & $15(0.16)$ & $6(0.19)$ & $19(0.24)$ & Ref & & Ref & & Ref & \\
\hline Lys/Gln & $34(0.49)$ & $32(0.51)$ & $11(0.35)$ & $35(0.44)$ & $1.54(0.65-3.64)$ & 0.33 & $1.16(0.50-2.65)$ & 0.73 & $0.99(0.32-3.11)$ & 0.61 \\
\hline $\mathrm{Gln} / \mathrm{Gln}$ & $23(0.33)$ & $46(0.49)$ & $14(0.45)$ & $25(0.32)$ & $1.46(0.58-3.65)$ & 0.42 & $2.33(1.01-5.37)$ & 0.04 & $1.77(0.57-5.47)$ & 0.32 \\
\hline Lys & $58(0.42)$ & $62(0.33)$ & $23(0.38)$ & $73(0.46)$ & Ref & & Ref & & Ref & \\
\hline Gln & $80(0.58)$ & $124(0.67)$ & $39(0.63)$ & $85(0.54)$ & $1.18(0.75-1.88)$ & 0.47 & $1.72(1.11-2.66)$ & 0.01 & $1.45(0.80-2.66)$ & 0.22 \\
\hline
\end{tabular}

Tab. VI. The genotype and allele frequency and odds ratios (OR) of the gene polymorphisms in open-angle glaucoma (POAG) patients based on the neuroretinal rim area (RA).

Tab. VI. Rozkład genotypów i częstotliwość alleli oraz iloraz szans (OR) dla polimorfizmów genów w grupie pacjentów z jaskrą pierwotną otwartego kąta przesączania (JPOK) oraz grupie kontrolnej w odniesieniu do parametru powierzchni rąbka nerwowo-siatkówkowego (RA).

\begin{tabular}{|c|c|c|c|c|c|c|c|c|}
\hline $\begin{array}{l}\text { Clinical } \\
\text { parameter }\end{array}$ & Stage of POAG & $\begin{array}{l}\text { Number of } \\
\text { POAG }\end{array}$ & $\begin{array}{c}\text { Mean (expression } \\
\text { level - Ct })\end{array}$ & $\begin{array}{c}\text { SEM (expression } \\
\text { level - Ct })\end{array}$ & $\begin{array}{c}\text { Quartile } \\
25 \%\end{array}$ & Median & $\begin{array}{c}\text { Quartile } \\
75 \%\end{array}$ & $\mathbf{p}$ \\
\hline \multirow{3}{*}{ NFI } & Normal $(0-30)$ & 16 & 2.090 & 1.311 & -0.340 & 0.317 & 1.660 & \multirow{3}{*}{0.748} \\
\hline & Early (31-50) & 8 & 0.188 & 0.282 & -0.613 & 0.317 & 0.813 & \\
\hline & Advanced (>51) & 11 & 0.975 & 0.427 & 0.0413 & 0.305 & 1.510 & \\
\hline \multirow{3}{*}{$c / d$} & Normal $(<0.3)$ & - & - & - & - & - & - & \multirow{3}{*}{$0.01 / 0,858$} \\
\hline & Early (0.3-0.7) & 15 & 0.689 & 0.491 & -0.748 & 0.48 & 1.622 & \\
\hline & Advanced ( $>0.7)$ & 23 & 1.715 & 0.903 & -0.180 & 0.330 & 0.976 & \\
\hline \multirow{4}{*}{ RA } & Normal (1.39-1.78) & 11 & 0.754 & 0.626 & -0.748 & -0.250 & 1.531 & \multirow{4}{*}{0.925} \\
\hline & Early (1.26-1.38) & 1 & 0.305 & & 0.305 & 0.305 & 0.305 & \\
\hline & Moderate -advanced (0.81-1.25) & 14 & 1.422 & 1.090 & -0.250 & 0.337 & 0.480 & \\
\hline & Advanced (<0.81) & 11 & 1.890 & 1.363 & 0.0300 & 0.330 & 1.510 & \\
\hline \multirow{3}{*}{ RNFL } & Normal $(0.21-0.31)$ & 5 & 1.390 & 1.387 & -1.775 & 1.660 & 4.420 & \multirow{3}{*}{0.956} \\
\hline & Early(0.20-0.18) & 5 & 0.442 & 0.367 & 0.0150 & 0.470 & 1.145 & \\
\hline & Moderate -advanced $(0.13-0.17)$ & 24 & 1.665 & 0.872 & -0.340 & 0.330 & 1.510 & \\
\hline
\end{tabular}

Tab. VII. Analysis of ADPRT gene expression level depending on the clinical parameters in patients with primary open angle glaucoma (POAG) for each eye counted.

Tab. VII. Analiza poziomu ekspresji genu ADPRT w odniesieniu do parametrów klinicznych w grupie pacjentów z jaskrą pierwotną otwartego kąta przesączania (JPOK) oraz grupie kontrolnej dla każdego zliczonego oka. 


\begin{tabular}{|c|c|c|c|c|c|c|c|c|}
\hline $\begin{array}{c}\text { Clinical } \\
\text { parameter }\end{array}$ & Stage of POAG & $\begin{array}{l}\text { Number } \\
\text { of POAG }\end{array}$ & $\begin{array}{c}\text { Mean (expression } \\
\text { level - Ct })\end{array}$ & $\begin{array}{l}\text { SEM (expression } \\
\text { level - Ct) }\end{array}$ & $\begin{array}{c}\text { Quartile } \\
25 \%\end{array}$ & Median & $\begin{array}{c}\text { Quartile } \\
75 \%\end{array}$ & PANOVA \\
\hline \multirow{3}{*}{ NFI } & Normal (0-30) & 16 & 3.454 & 1.581 & 0.560 & 0.605 & 1.465 & \multirow{3}{*}{0.104} \\
\hline & Early (31-50) & 6 & 4.775 & 3.970 & 0.420 & 0.685 & 1.930 & \\
\hline & Advanced (>51) & 11 & 4.095 & 2.124 & 0.985 & 1.210 & 4.750 & \\
\hline \multirow{3}{*}{$c / d$} & Normal $(<0.3)$ & - & & & & & & \multirow{3}{*}{0.724} \\
\hline & Early (0.3-0.7) & 15 & 4.853 & 2.162 & 0.455 & 0.985 & 6.134 & \\
\hline & Advanced $(>0.7)$ & 21 & 4.420 & 1.473 & 0.685 & 1.210 & 5.690 & \\
\hline \multirow{4}{*}{ RA } & Normal (1.39-1.78) & 11 & 3.953 & 2.234 & 0.455 & 0.685 & 5.846 & \multirow{4}{*}{0.421} \\
\hline & Early (1.26-1.38) & 2 & 7.018 & 5.662 & 1.355 & 7.018 & 12.680 & \\
\hline & Moderate -advanced (0.81-1.25) & 13 & 3.267 & 1.823 & 0.597 & 1.355 & 2.069 & \\
\hline & Advanced $(<0.81)$ & 13 & 5.398 & 2.190 & 0.676 & 1.210 & 7.438 & \\
\hline \multirow{3}{*}{ RNFL } & Normal (0.21-0.31) & 4 & 3.833 & 2.145 & 0.130 & 4.048 & 7.535 & \multirow{3}{*}{0.563} \\
\hline & Early $(0.20-0.18)$ & 5 & 0.944 & 0.221 & 0.619 & 0.685 & 1.410 & \\
\hline & Moderate -advanced (0.13-0.17) & 27 & 5.519 & 1.568 & 0.605 & 1.210 & 5.690 & \\
\hline
\end{tabular}

Tab. VIII. Analysis of XRCC1 gene expression level depending on the clinical parameters in patients with primary open angle glaucoma (POAG) for each enrolled eye.

Tab. VIII. Analiza poziomu ekspresji genu XRCC1 w odniesieniu do parametrów klinicznych w grupie pacjentów z jaskrą pierwotną otwartego kąta przesączania (JPOK) oraz grupie kontrolnej dla każdego zliczonego oka.

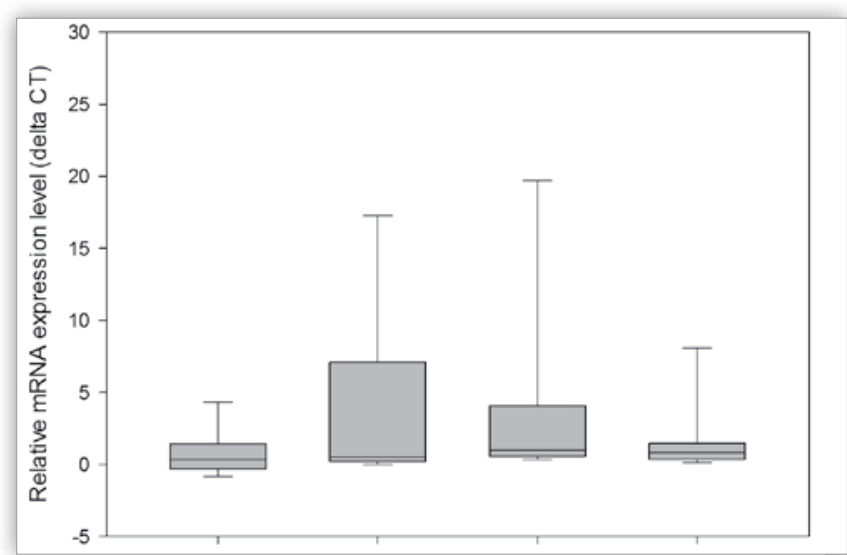

Fig. 1. Comparison of mRNA expression levels of XRCC1 and ADPRT genes in patients with primary open-angle glaucoma (POAG) vs control groups measured using the real-time PCR. Error bars represent the means $\pm S E M ; U$ test, $p<0.01$.

Ryc. 1. Porównanie poziomów ekspresji mRNA dla genów XRCC1 i ADPRT w grupie pacjentów z jaskrą pierwotną otwartego kąta przesączania (JPOK) w odniesieniu do grupy kontrolnej oznaczanych za pomocą reakcji PCR w czasie rzeczywistym. Słupki błędów reprezentują średnie \pm SEM; Test $U, p<0,01$.

XRCC1 and ADPRT in the blood of POAG patients and healthy subjects is presented in Figure 1. There were no significant differences in XRCC1 or ADPRT expression between the POAG patients and controls. Furthermore, Tables 7 and 8 correlate gene expression against clinical parameters in POAG patients separately for each eye. There was no significant relationship between $A D P R T$ and XRCC1 expression and POAG progression based on the studied clinical parameters.

\section{Discussion}

Glaucoma is a multifactorial neurodegenerative disorder which causes irreversible vision loss. Our findings indicate that oxidative stress, which is known to induce oxidative DNA damage, may be one of the most important factors in neurodegeneration. DNA repair is crucial for protecting the mammalian genome from numerous endogenous and environmental factors. The presence of some genetic alterations has previously been found to play an important role in glaucoma susceptibility, and the presence of polymorphisms in genes encoding main DNA repair enzymes may reduce DNA repair capacity or influence the transcription or translation of key proteins. This may lead to genetic instability, carcinogenesis or neurodegeneration. It has been emphasized that the oxidative DNA lesions induced by oxidative stress may lead to neurodegeneration in different parts of the brain (19).

The present study examines the relationship between the risk of POAG development and the presence of SNPs in genes encoding the main enzymes in the BER and NER pathways, an area which few studies have addressed to date. Our previous outcomes indicate that patients with POAG had decreased BER activity and more oxidative DNA lesions than healthy controls. As previous studies have already found the $399 \mathrm{Arg} / \mathrm{G} \ln X R C C 1$ gene polymorphism to be associated with an increased risk of POAG development $(20,21)$, the present study examines the more recently-discovered genetic polymorphisms in genes encoding key BER enzymes. Two such polymorphisms were selected: -77 T/C XRCC1 and G1672A ADPRT.

It has been proposed that $-77 \mathrm{~T} / \mathrm{C} X R C C 1$ is associated with reduced expression of $X R C C 1$; however, little information is available about its role in the pathogenesis of cancers and neurodegeneration. Nevertheless, our findings indicate a significant association between the presence of $-77 \mathrm{~T} / \mathrm{C} X R C C 1$ and the risk of POAG: patients with the $-77 \mathrm{~T} / \mathrm{C}$ genotype demonstrated a 0.62 -fold decrease in POAG risk. Unfortunately, no information is available on the role of this polymorphism in neurodegene- 
ration, as all appropriate studies address its relationship with cancers. For example, Hao et al. report a 1.44-fold increase in lung cancer risk for patients with $-77 \mathrm{~T} / \mathrm{C}$ genotype (9). Furthermore, our present analysis based on the cup-to-disc ratio found a 0.47 -fold decrease in POAG progression for patients with the TC genotype and 0.70 -fold decrease for those with the $C$ allele. Unfortunately, as this is the first study to focus on the role of $-77 \mathrm{~T} / \mathrm{C}$ XRCC1 in POAG pathogenesis, there is no available data to compare our results with.

The next part of the study examined the G1672A ADPRT polymorphism, located in the promoter region of the gene. This SNP has been associated with a range of conditions: Recent studies indicate a relationship between ADPRT and inflammation, and inhibition of ADPRT activity has been found to play an important role in cardiovascular, diabetes and stroke protection $(22,23)$. In the presented study, however, no direct relationship was found between the presence of G1672A ADPRT and POGA development. Although no publications could be found that examine the role of G1672A ADPRT in ocular disease, it has been suggested that it may play a role in Parkinson's disease (24). Our own analysis based on cup-to-disc ratio found a 3.03-fold increase of POAG progression in patients with GA genotype compared to those without. In addition, an analysis based on the RA parameter found that the presence of the GA genotype increased the risk of POAG progression 6.67-fold, whereas the $G$ allele increased it 3.03-fold.

Although a growing number of studies indicate that NER participates in oxidative DNA damage repair, this role remains poorly understood. Some reports suggest that NER may protect against oxidative stress. D'Errico et al. report that XPC cells are sensitized to protect the genome against DNA-oxidizing agents by the accumulation of oxidative DNA damage (25) and Yang et al. demonstrate that NER and BER cooperate rather than compete with each other (26).

The present study focuses on two selected SNPs. The first was 939 Lys/Gln of XPC, a well-studied SNP which induces a switch from lysine to glutamine in the protein. XPC is a 940 amino acid protein engaged in genome repair, which binds to RAD23B to form a complex (XPC-RAD23B) responsible for recognizing damaged sites and initiating DNA repair; it may also interact with TFIlH (19). Although the presence of $939 \mathrm{Lys} / \mathrm{Gln}$ $X P C$ is believed to be linked with an increased risk of breast cancer (27), our present findings do not indicate that it is associated with the development of POAG. Furthermore, our analysis found the 939 AC genetic polymorphism of XRCC1 to be significantly related to the RA parameter.

The study then analyzed the $751 \mathrm{Lys} / \mathrm{G} \ln$ XPD SNP, which has also been associated with cataract development (18). The XPD protein possesses ATP-dependent DNA helicase activity and may play an important role in removing oxidative DNA damage. However, the occurrence of non-synonymous amino acid changes in XPD may significantly alter the NER pathway (28). Our findings found the SNP to be associated with a 1.59fold greater risk of POAG development; these are in accordance with Yousaf et al, who found it to be associated with POAG development in a Turkish population (17).

The next objective of our work was to identify an association between DNA repair gene expression and POAG develop- ment. No significant difference in XRCC1 and ADPRT expression was found between patients with POAG and controls. Our results may be explained by some in vitro studies. Dhenaut et al. postulate that neither oxidative nor genotoxic stress induce changes in the mRNA expression of DNA repair genes (29). Furthermore, it was indicated that increased DNA repair gene expression at the mRNA level is not required for efficient DNA repair. DNA repair mechanisms are multistep procedures that are regulated at numerous levels including the transcription and post-translational modification stages (30), and BER proteins can be subject to phosphorylation, acetylation and ubiquitination, which will affect their repair ability (31).

To conclude, alterations in the structure of $A D P R T, X R C C 1$ and XPD genes appear to modulate the risk of POAG development. Furthermore, both the BER and NER pathways may play a role in POAG development.

\section{Acknowledgments \\ Authors thank Dr Alicja Nowak and Dr Magda Cuchra for their technical participation. This work was supported by grant no. 2016/21/B/NZ5/01411 from National Science Centre, and no. 503/5-108-05/503-51-0006 form Medical University of Lodz, Poland.}

\section{Bibliography}

1. Quigley HA, Broman AT: The number of people with glaucoma worldwide in 2010 and 2020. Br J Ophthalmol, 2006. 90(3): p. 262-267.

2. Alvarado J, Murphy C, Juster R: Trabecular meshwork cellularity in primary open-angle glaucoma and nonglaucomatous normals. Ophthalmology, 1984. 91(6): p. 564-579.

3. Izzotti A, Bagnis A, Sacca SC: The role of oxidative stress in glaucoma. Mutat Res, 2006. 612(2): p. 105-114.

4. Zhou L, Li Y, Yue BY: Oxidative stress affects cytoskeletal structure and cell-matrix interactions in cells from an ocular tissue: the trabecular meshwork. J Cell Physiol, 1999. 180(2): p. 182-189.

5. Majsterek I, et al.: ABL-fusion oncoproteins activate multi-pathway of DNA repair: role in drug resistance? Biochimie, 2004. 86(1): p. 53-65.

6. Caldecott KW: XRCC1 and DNA strand break repair. DNA Repair (Amst), 2003. 2(9): p. 955-969.

7. Tebbs RS, et al.: Requirement for the Xrcc1 DNA base excision repair gene during early mouse development. Dev Biol, 1999. 208(2): p. 513-529.

8. Berrington de Gonzalez A, et al.: Anthropometry, physical activity, and the risk of pancreatic cancer in the European prospective investigation into cancer and nutrition. Cancer Epidemiol Biomarkers Prev, 2006. 15(5): p. 879-885.

9. Hao $\mathrm{B}$, et al.: A novel T-77C polymorphism in DNA repair gene XRCC1 contributes to diminished promoter activity and increased risk of non-small cell lung cancer. Oncogene, 2006. 25(25): p. 3613-3620.

10. Pascual $\mathrm{M}$, et al.: A poly(ADP-ribose) polymerase haplotype spanning the promoter region confers susceptibility to rheumatoid arthritis. Arthritis Rheum, 2003. 48(3): p. 638-641.

11. Berquist BR, Wilson DM: $3^{\text {rd }}$, Nucleic acid binding activity of human Cockayne syndrome $B$ protein and identification of $\mathrm{Ca}(2+)$ as a novel metal cofactor. J Mol Biol, 2009. 391(5): p. $820-832$. 
12. Melis JP, van Steeg $\mathrm{H}$, Luijten M: Oxidative DNA damage and nucleotide excision repair. Antioxid Redox Signal, 2013. 18(18): p. 2409-2419.

13. D'Errico M, Parlanti E, Dogliotti E: Mechanism of oxidative DNA damage repair and relevance to human pathology. Mutat Res, 2008. 659(1-2): p. 4-14.

14. Friedberg EC: How nucleotide excision repair protects against cancer. Nat Rev Cancer, 2001. 1(1): p. 22-33.

15. Banescu C, et al.: Polymorphism of XRCC1, XRCC3, and XPD genes and risk of chronic myeloid leukemia. Biomed Res Int, 2014. 2014: p. 213790.

16. Benhamou S, Sarasin A: ERCC2/XPD gene polymorphisms and cancer risk. Mutagenesis, 2002. 17(6): p. 463-469.

17. Yousaf $S$, et al.: XRCC1 and XPD DNA repair gene polymorphisms: a potential risk factor for glaucoma in the Pakistani population. Mol Vis, 2011. 17: p. 1153-1163.

18. Unal $\mathrm{M}$, et al.: Polymorphisms of DNA repair genes XPD and XRCC1 and risk of cataract development. Exp Eye Res, 2007. 85(3): p. 328-334.

19. He J, et al.: Associations of Lys939GIn and Ala499Val polymorphisms of the XPC gene with cancer susceptibility: a meta-anaIysis. Int J Cancer, 2013. 133(8): p. 1765-1775.

20. Cuchra $\mathrm{M}$, et al.: The role of base excision repair in the development of primary open angle glaucoma in the Polish population. Mutat Res, 2015. 778: p. 26-40.

21. Szaflik JP, et al.: Association of the 399Arg/GIn XRCC1, the 194 Arg/Trp XRCC1, the 326Ser/Cys OGG1, and the 324G/n/His MUTYH gene polymorphisms with clinical parameters and the risk for development of primary open-angle glaucoma. Mutat Res, 2013. 753(1): p. 12-22.
22. Peralta-Leal $\mathrm{A}$, et al.: PARP inhibitors: new partners in the therapy of cancer and inflammatory diseases. Free Radic Biol Med, 2009. 47(1): p. 13-26.

23. Giansanti V, et al.: PARP inhibitors: new tools to protect from inflammation. Biochem Pharmacol, 2010. 80(12): p. 1869-1877.

24. Koc A, et al.: Association of three SNPs in the PARP-1 gene with Hashimoto's thyroiditis. Hum Genome Var, 2014. 1: p. 14016.

25. D'Errico M, et al.: New functions of XPC in the protection of human skin cells from oxidative damage. EMBO J, 2006. 25(18): p. 4305-4315.

26. Yang W: Poor base stacking at DNA lesions may initiate recognition by many repair proteins. DNA Repair (Amst), 2006. 5(6): p. 654-666.

27. Yang X, et al.: Association of XPC polymorphisms with susceptibility and clinical outcome to chemotherapy in breast cancer patients. Cancer Sci, 2012. 103(7): p. 1207-1214.

28. Lehmann AR: The xeroderma pigmentosum group $D$ (XPD) gene: one gene, two functions, three diseases. Genes Dev, 2001. 15(1): p. 15-23.

29. Dhenaut A, Boiteux S, Radicella JP: Characterization of the hOGG1 promoter and its expression during the cell cycle. Mutat Res, 2000. 461(2): p. 109-118.

30. Molasy $\mathrm{M}$, et. al.: MicroRNAs in glaucoma and neurodegenerative diseases. J Hum Genet, 2017. 62(1): p. 105-112.

31. Harper JW, Elledge SJ: The DNA damage response: ten years after. Mol Cell, 2007. 28(5): p. 739-45.

The paper was originally received 02.05.2018 (KO-00159-2018)/

Praca wpłynęła do Redakcji 02.05.2018 (K0-001-2018)

Accepted for publication 10.03.2019/

Zakwalifikowano do druku 10.03.2019.

Reprint requests to (Adres do korespondencji): prof. Ireneusz Majsterek,

Department of Clinical Chemistry and Biochemistry,

Medical University in Lodz, Lodz, Poland.

tel: +48 426393306 ,

e-mail: ireneusz.majsterek@umed.lodz.pl

\section{Redakcja kwartalnika medycznego OKULISTYKA e-mail: redakcja@okulistyka.com.pl}

